\title{
Studi Meningkatkan Kepercayaan Diri Anak Untuk Memimpin
}

\author{
Pretty Bona Vide Gulo \\ STAK Terpadu PESAT \\ Prettybonavidegulo9@gmail.com
}

\begin{abstract}
Abstraksi
Tujuan dari tulisan ini adalah untuk mendapatkan pemahaman yang baik tentang meningkatkan kepercayaan diri anak dan memimpin, sangat penting dalam diri seseorang untuk memiliki keberanian diri untuk memimpin, dalam diri seseorang sangat penting untuk menanamkan sikap seorang pemimpin. Penelitian tentang studi meningkatkan kepercayan diri anak untuk memimpin, menggunakan studi pustaka menurut Zed adalah serangkaian kegiatan yang berkenaan dengan metode pengumpulan data pustaka, membaca dan mencatat serta mengelolah bahan penelitian. Dan menurut Sugito kepustakaan berfungsi sebagai dasar ilmiah terhadap permasalahan yang dicoba. Dasar ilmia in sangat penting dan harus dipahami karna yang dilakukan adalah penelitian ilmiah, bukan sekedar mencoba-coba (trial and error) ${ }^{1}$ Setiap orang pemimpin, karna kepemimpinan itu sudah ada dalam diri seseorang sejak lahir, oleh karena itu semua orang pemimpin dan setiap orang membutukan orang lain untuk memotivasi, dan memberi semangat, jadi kepemimpinan yang sudah ada dalam diri seseorang harus di kembangkan, dengan cara menumbukan rasa percaya diri individu.
\end{abstract}

Kata Kunci : Kepercayaan Diri Anak Memimpin

\begin{abstract}
The purpose of this paper is to get a good understanding of increasing children's self-confidence and leading. It is very important in a person to have the courage to lead, in a person it is very important to instill the attitude of a leader. Research on studies increases children's selfconfidence to lead, using literature study according to Zed is a series of activities relating to methods of collecting library data, reading and taking notes and managing research materials. And according to Sugito literature serves as a scientific basis for the problems being tried. This scientific basis is very important and must be understood because what is done is scientific research, not just trial and error. Every person is a leader, because leadership is already present in a person from birth, therefore all leaders and everyone needs others to motivate, and encourage,
\end{abstract}

\footnotetext{
${ }^{1}$ Devan Firmansyah dan Febby Soesilo, Sejarah Daerah Malang Timur (Malang: Wisma Kalimetro, Jl. joyusuko Metro 42 Malang, 2020), 13.
} 
so the leadership that is already in a person must be developed, by fostering individual selfconfidence.

Keywords: Child Confidence Leadin.

\section{A. Pendahuluan}

Dalam studi meningkatkan kepercayaan diri merupakan sesuatu hal yang harus dipersiapkan dalam diri seseorang, Karna kepercayaan diri merupakan modal dasar bagi keberhasilan seseorang di segala bidang. Oleh karena itu sangat penting untuk menanamkan kepercayaan diri kepada anak untuk meningkatkan sikap kepemimpinannya. Karena dalam diri seseorang sudah ada kepemimpin sejak lahir, maka syarat-syarat sebagai pemimpin perlu untuk ditanamkan kepercayaan diri dan dilati terus-menerus.

Sangat penting dalam diri anak untuk memiliki kepercayaan diri, ketikan individu memiliki kepercayan diri maka ia akan mampu menguasai bidang tertentu dan lebih mudah menyerap hal-hal yang diinformasikan dikemudia hari, jadi kepercayaan diri merupakan hal yang sangat penting yang harus dimiliki oleh anak, oleh karena itu sangat perluh untuk meningkatkan kepercayaan diri kepada setiap individu, supaya setiap anak memiliki rasa percaya dirinya semakin bertumbuh dan mampu memiliki keberanian untuk memimpin. Dan kepercayaan diri merupkan kepribadian seseorang yang sangat berfungsi penting untuk mengatualisasikan potensi yang dimilikiny. ${ }^{2}$ jadi sangat penting dalam diri individu untuk dikembangkan kepercayaan dirinya untuk memimpin.

Dalam meningkatkan kepercayaan diri anak untuk memimpin, maka diperlukan pemimpin visioner yang dapat mengidentifikasi seseorang dengan tujuan menolong dan memotivasi dan memiliki keberanian memimpin terus-menerus kedepannya. Jadi tidak dipungkiri bahwa dalam kepemimpinan harus ada peningkatan-peningkatan yang dialami, baik dalam memimpin diri sendiri atau orang lain.

Tetapi ada peningkatan kepercayaan diri yang harus dikembangan untuk setiap orang yang dipimpin, agar mengalami peningkatan perubahan kepemimpinan,

\footnotetext{
2 Tina Afiatin and Sri Mulyani Martaniah, "Peningkatan Kepercayaan Diri Remaja Melalui Konseling Kelompok," Psikologika: Jurnal Pemikiran dan Penelitian Psikologi 3, no. 6 (1998): 66-79.
} 
cantohnya sebelum seorang pemimpin yang ingin meningkatkan kepemimpinan dalam sebuah komunitas, kolompok kecil atau dalam diri seseorang yang perlu di tingkatkan kepemimpinannya, maka faktofaktor yang dapat mempengaruhi kepemimpinan harus diperhatikan.

\section{Dalam memperhatikan factor-faktor} tersebut seorang pemimpin harus melatih diri untuk meningkatkan kapasitas baik dalam diri seorang pemimpin, orang yang dipimpin maupun situasi waktu kepemimpinan kita terlaksana. Jadi seorang pemimpin adalah harus mengetujui tugas kepemimpinannya dan dapat membawa perubahan dalam diri seseorang dan dapat mengetahui tujuannya bahwa kepemimpinan itu berasal dari diri sendiri. Dan harus memiliki kepercayaan diri untuk memimpin orang-orang yang dia pimpin.

\section{Dalam kepemimpinan memiliki} kelompok gaya kepemimpinan, sering kali menjadi pengaruh yang secara tidak langsung memberikan kenyamanan bagi orang yang dipimpin. Gaya kepemimpinn adalah pola menyeluru dari tindakan seorang pimimpin baik yang tampak maupun yang

\footnotetext{
${ }^{3}$ Marsam. Pengaruh Gaya Kepemimpinan, Kompetensi dan Komitmen Terhadap Kinerja Pengawai Pada Unit Pelaksana Teknis (UPT) Di
}

tidan nampak oleh bawahannya. ${ }^{3}$ jadi dalam satu kelompok gaya dapat mempengaruhi pemimpin yang dipersiapakan selanjutnya. Secara khusus pemimpin yang dipersiapkan sejak dini

Kepemimpinan sudah ada sejak lahir. Sala satu kepemimpinan anak adalah kecenderungan menjadi pemimpin yang alamiah yang akan menentukan apa yang akan dilakukan selanjutnya dalam sekelompok anak, dan dia dapat menarik kesimpulan, dan dapat bertanggung jawab atas setiap tidakan kepemimpinan yang dilakukannya. ${ }^{4}$

Dalam membangun kepemimpinan anak usia dini sangan penting, ada banyak orang yang tidak peduli untuk membangun kepemimpinan anak sejak usia dini. Jika kepemiminan anak tidak dibangun sejak usia dini, maka anak akan mengalami masalah dalam dirinya. tidak berani memimpin dan tidak memiliki kepercayaan diri untuk tampil didepan memimpin temanya. Jadi dalam diri anak sangat perlu membangu kepemimpinan sejak usia dini. Karna ketika diberi kesempatan kepada anak untuk memimpin orang lain, dia akan mulai

LIngkungan Yapis Cabang Kabupaten Biak Numfor, (Qiara Media-Pasuran, JawaTimur:2020) hal. 10. ${ }^{4}$ Vemi Olivia, kembangkan kecerdikan anak dengan takti biosmart, (Jakarta 2009) hal. 18-19. 
menumbuhkan rasa kepecayaan dirinya untuk tampil memimpi orang lain dan memiliki kepercayaan diri. Jadi dalam hal ini, perang guru sangat penting untuk menumbukan rasa kepercayaan diri anak dalam sentra main peran, guru harus memberi kesempatan kepada anak untuk memimpi temannya dalam kegiatan apa saja di sentra main peran.

\section{Metodologi Penelitian}

Metodologi penelitian kepustakaan menurut Zed adalah serangkaian kegiatan yang berkenaan dengan pengumpulan data pustaka, membaca, dan mencatat serta mengelola setiap bahan penelitian. ${ }^{5}$ jadi studi kepustakaan dapat dilakukan dengan cara menggunakan jurnal, majala dan setiap buku yang dapat digunakan untuk diteliti dan dapat menghasilkan sebuah karya ilmia.

\section{PEMBAHASAN}

\section{Meningkatkan Kepercayaan Diri Anak}

\section{Untuk Memimpin}

\section{Kepercayaan Diri}

Meningkatkan adalah menaikan (derajat, taras, dsb); mempertinggi; memperhebat

\footnotetext{
${ }^{5}$ Soesilo, Sejarah Daerah Malang Timur, 13.

${ }^{6}$ Kamus besar bahasa Indonesia (KBBI) Hal. 1060.

${ }^{7}$ Aprianti Yofita Rahayu Menumbukan Kepercayaan Diri Melalui Kegiatan bercerita (PT Indeks 2013) Hal. 62-63
}

(produksi sbb); mengangkat diri; diri mengkat diri; memegakan diri mereka akan mampu penghidupannya. ${ }^{6}$ Jadi sangant penting untuk memberi kepercayaan diri kepada setiap anak untuk meningkatkan dan mengembangan kepercayaan diri yang dia miliki sesorang untuk memimpin

Kepercayaan diri menurut Oxford Advanced Learner's Dictionary mendefinisikan kepercayaan diri merupakan kemampuan sendiri untuk sesuatu dan dapat berhasil dengan baik. Pendapat yang serupa juga menurut Goleman menyatakan bahwa kepercayaan diri adalah kesadaran yang kuat tentang harga dan kemampuan diri sendiri. ${ }^{7}$ Jadi kepercayaan diri adalah kapasilitas seseorang untuk mencapai keberhasilan yang baik dimasa yang akan datang, dan dapat mennyadari setiap bakat yang ada dalam dirinya. Sedangkan menurut Rakhmat kepercayaan diri atau keyakinan diri, di artikan sebagai kepercayaan terhadap diri sendiri yang dimiliki setiap individu, dan individu tersebut dapat memandang dirinya secara utuh dengan mengacu pada konsep diri sendiri. ${ }^{8}$ Oleh karena itu dapat disimpulkan bahwa kepercayaan diri dapat

\footnotetext{
${ }^{8}$ Heris Hendriana, "Pembelajaran Matematika Humanis Dengan Metaphorical Thinking Untuk Meningkatkan Kepercayaan Diri Siswa," Infinity Journal 1, no. 1 (2012): 90-103.
} 
dimiliki setiap orang dan setiap orang juga

harus memacu dan meningkatkan

kepercayaan diri yang dimilikinya. Pearce

mengemukakan bahwa kepercayaan diri

tindakan, kegiatan, dan usaha untuk

bertindak bukan menghindari setiap keadaan

yang pasif. Namun pendapat ini diperkuat

oleh Hakim kepercayaan diri adalah

kepercayaan yang dilakukan seseorang

dalam segala aspek kelebihan yang dapat

dimilikinya untuk kemampuan mencapai

dalam hudupnya. ${ }^{9}$ jadi kepercayaan diri

adalah sikap dan kelakuan yang dapat

dilakukan seorang individu dalam segala

aspek yang dapat dilakukannya.

Kepercayaan diri sangat dibutukan oleh sesorang untuk mengoptimalkan setiap potensi yang dimiliki individu. Hal ini senada dengan Lauster Hendriana kepercayaan diri merupakan sikap perasaan yang meyakinkan dengan kemampuan diri sendiri sehingga individu tidak memiliki kecamasan untuk melakukan hal-hal yang disukainya dan memiliki interasi yang baik dengan orang lain. ${ }^{10}$ oleh karena itu kepercayaan diri merupakan sikap

\footnotetext{
${ }^{9}$ Menumbukan kepercayaan diri melalui kegiatan bercerita, No Title (PT Indeks, 2013).

${ }^{10}$ Chandra Novtiar and Usman Aripin, "Meningkatkan Kemampuan Berpikir Kritis Matematis Dan Kepercayaan Diri Siswa SMP Melalui Pendekatan Open Ended," Prisma 6, no. 2 (2017): 119-131.
}

keyakinan seseorang untuk meyakinkan dengan mengembangkan kemampuan atau potensi yang dimiliki seseorang.

Menurut Surya kepercayaan diri adalah keyakinan individu terhadap segala aspek yang dimilikinya dan diwujudkan dalam tingkah lakunya sehari-hari serta bagaimana ia menilai diri sendiri dan lingkungan secara positif. ${ }^{11}$ Jadi dapat disimpulkan bahwa untuk meningkatkan kepercayaan diri individu harus memiliki keyakinan dan berpikir positif terhadap dirinya dan orang lain. Hal ini sependapat dengan Surhardita mengatakan bahwa kepercayaan diri dapat dibentuk melalui pengalaman yang di alami dan yang pernah dilakukan oleh setiap individu sehari-hari. ${ }^{12}$ jadi kepercayaan diri individu dapat di tingkatkan dengan pengalaman yang di alami setiap hari, oleh karena itu sangat pentinglah guru dan orang tua memberi kesempatan kepada anak untuk menceritakan apa yang dirasakan dan memberi kesempatan untuk memimpin teman-temannya, supaya setiap individu memiliki kepercayaan diri untu

\footnotetext{
11 Ifdil Ifdil, Amandha Unzilla Denich, and Asmidir Ilyas, "Hubungan Body Image Dengan Kepercayaan Diri Remaja Putri," Jurnal Kajian Bimbingan dan Konseling 2, no. 3 (2017): 107-113. 12 Ibid.
} 
menceritakan apa yang dirasakannya, dan dapat memiliki keberanian memimpin.

Sedangkan menurut Perry kercayaan diri adalah kemampuan untuk memercayai kemampuan diri sendiri, untuk melakukan segala sesuatu dengan penuh keyakinan dan selalu siap menghadapi tatangan untuk mencapai keinginannya. Kpercayaan diri adalah kekuatan yang selalu mendorong individu untuk terus maju dan mau berkembang. ${ }^{13}$ jadi kepercayaan diri adalah kemampuan untuk mempercayai diri dan mengembangkan pontensi yang dimilikinya dengan penuh keyakinan. Jadi studi kepust

\section{KEPEMIMPINAN}

Kepemimpinan sudah ada sejak lahir.

Sala satu kepemimpinan anak adalah kecenderungan menjadi pemimpin yang alamiah yang akan menentukan apa yang akan dilakukan selanjutnya dalam sekelompok anak, dan dia dapat menarik kesimpulan, dan dapat bertanggung jawab atas setiap tidakan kepemimpinan yang dilakukannya. ${ }^{14}$ Oleh karena itu dalam membangun kepemimpinan anak usia dini

\footnotetext{
${ }^{13}$ Hendro Bidjuni, "Hubungan Kepercayaan Diri Dengan Penyesuaian Diri Pada Mahasiswa Baru Di Program Studi IImu Keperawatan Fakultas Kedokteran Universitas Sam Ratulangi Manado," Jurnal Keperawatan 4, no. 2 (2016).
}

sangan penting, ada banyak orang yang tidak peduli untuk membangun kepemimpinan anak sejak usia dini.

Jika kepemiminan anak tidak dibangun sejak usia dini, maka anak akan mengalami masalah dalam dirinya. tidak berani memimpin dan tidak memiliki kepercayaan diri untuk tampil didepan memimpin temanya. Jadi dalam diri anak sangat perlu membangu kepemimpinan sejak usia dini. Karna ketika diberi kesempatan kepada anak untuk memimpin orang lain, dia akan mulai menumbuhkan rasa kepecayaan dirinya untuk tampil memimpi orang lain dan memiliki kepercayaan diri.

Kepemimpinan adalah kemampuan seseorang untuk mempengaruhi orang lain, dalm hal ini bawahannya sedemikian rupa sehingga orang lain tersebut melakukan kehendak pimpinan meskinpun secara pribadi hal itu mungkin disenanginya. ${ }^{15}$ Kepemimpinan menurut Wahjosumidjo kemampuan yang ada pada diri seorang leader yang berupa sifat-sifat tertentu seperti kepribadaian, kemampuan, sesanggupan.

\footnotetext{
${ }^{14}$ Vemi Olivia, Perkembangan Kecerdikan Anak Dengan Taktik Biosmart (Jakarta: Elex Media Komputindo, 2009), 18-19.

15 Novianto Eko Nugroho Asmara Indahingwati, Manejeman Sumber Budaya Manusia (Surabaya: Scopindo, 2020), 124.
} 
Kepemimpinan meripakan rangkaian aktifitas kepemimpinan yang tidak dapat dipisakan dengan kedudukan, gaya dan perilaku pemimpin tersebut serta interaksi antara pemimpin, pengikut, dan situasi. Jadi kepemimpinan dalam hal ini, dapat disimpulkan bahwa seorang pemimpin harus mempengaruhi orang lain dan memiliki pengikut yang dapat di ajak untuk mengikuti setiap kehendak yang di inginkan seorang pemimpin.

Kepemimpinan menurut Hemhill dan Coons dalam Yulk (1994:2), kepemimpinan adalah perilaku seseorang dari individu yang memimpin aktivitas-aktivitas suatu kelompok kesuatu tujuan yang ingin dicapai bersama (shared goal. ${ }^{16}$ Jadi dengan berbagai kegiatan yang di lakukan seorang dalam suatu aktifitas atau kelompok harus memmiliki kerja sama yang baik dengan team worknya, aga dapat mencapai sebuah keinginan bersama dan hasinya dapat memuaskan pemimpin maupun pengikutnya.

Kepemimpinan adalah masalah pengaru dia dapat memberikan pengaru yang baik untuk dirinya sendiri maupun untuk orang lain agar orang lain juga melakukan apa yang ia katakana. ${ }^{17}$ Dalam membangun

\footnotetext{
${ }^{16}$ Tjahjoanggoro. Agus Wijaya, Purnomolastu, Kepemimpinan Berkarakter (Yogyakarta: Brilian Internasional, 2015), 2.
}

kepemimpinan anak usia dini sangan penting, ada banyak orang yang tidak peduli untuk membangun kepemimpinan anak sejak usia dini. Jika kepemiminan anak tidak dibangun sejak usia dini, maka anak akan mengalami masalah dalam dirinya. tidak berani memimpin dan tidak memiliki kepercayaan diri untuk tampil didep an memimpin temanya. Jadi dalam diri anak sangat perlu membangu kepemimpinan sejak usia dini. Karna ketika diberi kesempatan kepada anak untuk memimpin orang lain, dia akan mulai menumbuhkan rasa kepecayaan dirinya untuk tampil memimpi orang lain dan memiliki kepercayaan diri. Jadi dalam hal ini, perang guru sangat penting untuk menumbukan rasa kepercayaan diri anak

Kepemimpin menurut Robert D Stuart adalah seseorng yang memiliki kemampaun untuk mempengaruhi, dan dapat memberikan petunjuk serta dapat menentukan individu untuk mencapai tujuan yang harus dicapai. James P. Spillane menyatakan bahwa kepemimpinan adalah agen perubahan serta mampu mempengaruhi orang-orang dengan kegiatan yang

\footnotetext{
${ }^{17}$ Hengki Irawan Setia Budi, 5 Relation Ships (Jakarta: Gramedia, 2011), 52.
} 
dilakukannya. ${ }^{18}$ jadi kepemimpinan adalah kemampuan seseorang untuk memberi pengaruh kepada pengikutnya dan sorang pemimpin harus menjadi agen perubahan kepada orang yang dipimpin.

\section{Kesimpulan}

Dalam tulisan ini dapat disimpulakan bahwa meningkatkan kepercayaan diri anak untuk memimpin sangat penting, oleh karna itu sangat penting dalam diri individu untuk menanamkan kepercayaan diri dalam diri individu, ketika seseorang memiliki

\section{DAFTAR PUSTAKA}

Afiatin, Tina, and Sri Mulyani Martaniah. "Peningkatan Kepercayaan Diri Remaja Melalui Konseling Kelompok.” Psikologika: Jurnal Pemikiran dan Penelitian Psikologi 3, no. 6 (1998): 66-79.

Agus Wijaya, Purnomolastu, Tjahjoanggoro. Kepemimpinan Berkarakter.

Yogyakarta: Brilian Internasional, 2015.

\footnotetext{
18 Irawaty A Kahar, “Konsep Kepemimpinan Dalam Perubahan Organisasi (Organizational Change) Pada Perpustakaan Perguruan Tinggi," Pustaha: Jurnal
}

kepercayaan diri maka ia akan memiliki keberanian untuk memimipin dan mengembangkan potensi yang dimilikinya. Setiap orang sudah menjadi pemipin sejak lahir, karna kepemimpinan itu adalah bawaan dari lahir, maka dari itu perlu dikembangkan lagi kepemimpinan seseorang melalui meningkatkan pepercayaan diri. Jadi setiap pemimpin harus me iliki kepercayan diri untuk membawa perubahan dam mempengaruhi orang lain dan orang yang dipimpinya akan dipersiapkan menjadi pemimpin yang handal.

Asmara Indahingwati, Novianto Eko Nugroho. Manejeman Sumber Budaya Manusia. Surabaya: Scopindo, 2020. Bidjuni, Hendro. "Hubungan Kepercayaan Diri Dengan Penyesuaian Diri Pada Mahasiswa Baru Di Program Studi Ilmu Keperawatan Fakultas Kedokteran Universitas Sam Ratulangi Manado.” Jurnal Keperawatan 4, no. 2 (2016). Budi, Hengki Irawan Setia. 5 Relation Ships.

Studi Perpustakaan dan Informasi 4, no. 1 (2008): 21-27. 
Jakarta: Gramedia, 2011.

Hendriana, Heris. "Pembelajaran

Matematika Humanis Dengan

Metaphorical Thinking Untuk

Meningkatkan Kepercayaan Diri

Siswa." Infinity Journal 1, no. 1

(2012): 90-103.

Ifdil, Ifdil, Amandha Unzilla Denich, and

Asmidir Ilyas. "Hubungan Body Image

Dengan Kepercayaan Diri Remaja

Putri." Jurnal Kajian Bimbingan dan

Konseling 2, no. 3 (2017): 107-113.

Kahar, Irawaty A. "Konsep Kepemimpinan

Dalam Perubahan Organisasi

(Organizational Change) Pada

Perpustakaan Perguruan Tinggi."

Pustaha: Jurnal Studi Perpustakaan

dan Informasi 4, no. 1 (2008): 21-27.

Menumbukan kepercayaan diri melalui

kegiatan bercerita. No Title. PT Indeks, 2013.

Novtiar, Chandra, and Usman Aripin.

"Meningkatkan Kemampuan Berpikir

Kritis Matematis Dan Kepercayaan Diri

Siswa SMP Melalui Pendekatan Open

Ended.” Prisma 6, no. 2 (2017): 119-

131.

Olivia, Vemi. Perkembangan Kecerdikan

Anak Dengan Taktik Biosmart. Jakarta:
Elex Media Komputindo, 2009.

Soesilo, Devan Firmansyah dan Febby. Sejarah Daerah Malang Timur. Malang: Wisma Kalimetro, Jl. joyusuko Metro 42 Malang, 2020. 